\title{
Sifat Fisikokimia dan Organoleptik Permen Susu (Karamel) Rasa Jahe (Zingiber officinale Roscoe) dan Temulawak (Curcuma xanthorriza Roxb)
}

\author{
Physical-chemical and Organoleptic Characteristics of Milk Candy (Caramel) with Ginger \\ (Zingiber officinale Roscoe) and Temulawak (Curcuma xanthorriza Roxb) Tastes \\ Sistanto, Edi Soetrisno, Rustama Saepudin
}

Jurusan Peternakan, Fakultas Pertanian, Universitas Bengkulu

Jalan W.R Soepratman Kandang Limun Bengkulu 38371 A

Email : tantoosis@gmail.com

\begin{abstract}
This research was aimed to describe characteristic of milk candy consisting of physical, chemical, and organoleptic appearances added with ginger and curcuma. Methodology used in this research was Completely Randomized Design with five treatments, P0: control, P1: 0.6\% ginger, P2: $1 \%$ ginger, P3: 0.6\% curcuma, and $\mathrm{P} 4: 1 \%$ curcuma. Variabels measured were rendement, density, $\mathrm{pH}$, moisture, ether extract, protein, Gross Energy (GE), and organoleptic tests consisting of color, aroma, taste, texture, tenderness, and general acceptance. Results showed that treatments did not show significant effects $(\mathrm{P}>0.05)$ on rendement $(40.84 \%)$, density $\left(0.933 \mathrm{~g} / \mathrm{cm}^{3}\right), \mathrm{pH}(5.36)$, moisture $(9.63 \%)$, ether extract $(6 \%)$, protein $(5.5 \%)$, GE (4098 Kcal) and tenderness $(4.80 \%)$. Treatments decreased acceptance of panelist for aroma $(37.5 \%-13.75 \%)$, color $(52.50 \%$ $18.75 \%)$, taste $(56.25 \%-11.25 \%)$, texture $(47.50 \%-7.50 \%)$ and overall product. The highest modus was found in P0 candy (58.75\%). Manufacturing milk into candy type was able to improve the quality of milk; however, addition of ginger and curcuma decreased acceptance of the panelists compared to the one without ginger and curcuma.
\end{abstract}

Key words: caramel, curcuma, ginger, physical- chemical, organoleptic characteristics

\begin{abstract}
ABSTRAK
Penelitian ini bertujuan untuk mendeskripsikan karakteristik produk permen susu (karamel) meliputi sifat fisik, kimia, dan organoleptik setelah adanya penambahan jahe dan temulawak. Metode penelitian ini menggunakan Rancang Acak Lengkap pola satu arah terdiri dari lima perlakuan dengan empat ulangan yaitu P0: Kontrol, P1: 0,6\% jahe, P2: $1 \%$ jahe, P3: 0,6\% temulawak, dan P4: \% temulawak. Variabel yang diukur meliputi rendemen, kerapatan, pH, kadar air, lemak, protein, Gross Energy (GE) dan uji organoleptik meliputi warna, aroma, rasa, tekstur, keempukan, dan produk secara umum. Hasil penelitian menunjukkan bahwa perlakuan tidak memberikan pengaruh yang nyata terhadap rataan jumlah rendemen $(40,84 \%)$, kerapatan $\left(0,933 \mathrm{~g} / \mathrm{cm}^{3}\right), \mathrm{pH}$ $(5,36)$, kadar air $(9,63 \%)$, lemak $(6 \%)$, protein $(5,5 \%)$, GE (4098 Kkal) dan keempukan $(4,80 \%)$. Perlakuan menurunkan tingkat kesukaan panelis dari parameter aroma $(37,5 \%-13,75 \%)$, warna $(52,50 \%-18,75 \%)$, rasa $(56,25 \%-11,25 \%)$, tekstur (47,50\%-7,50\%) serta produk secara keseluruhan. Modus kesukaan tertinggi pada permen karamel P0 (kontrol) sebesar 58,75\%. Pengolahan susu menjadi karamel dapat meningkatkan mutu produk karamel susu namun penggunaan jahe dan temulawak menurunkan persentase tingkat kesukaan panelis dibandingkan dengan karamel tanpa penambahan jahe dan temulawak.
\end{abstract}

Kata kunci: karamel, jahe, temulawak, fisik- kimia, organoleptik

\section{PENDAHULUAN}

Susu merupakan bahan makanan yang dihasilkan ternak perah baik sapi maupun kambing dengan kandungan nutrisi terlengkap dalam pemenuhan konsep gizi yang dikenal dengan empat sehat lima sempurna. Berbagai macam produk olahan susu sudah banyak dijumpai di berbagai pusat makanan baik yang berasal dari impor maupun produk dalam negeri. Menurut Afriani et al. (2011) susu merupakan makanan yang hampir 
sempurna, karena kandungan nutrisinya lengkap dan cukup untuk memenuhi kebutuhan hidup pokok manusia. Sebagaimana produk peternakan, susu sangat mudah mengalami kerusakan akibat pertumbuhan mikroorganisme patogen. Oleh karena itu, diperlukan suatu tindakan pengolahan susu untuk mempertahankan mutu produk susu.

Saat ini produk susu perah lokal baik kuantitas maupun kualitasnya belum mampu mencukupi permintaan Industri Pengolahan Susu (IPS), belum memenuhi milk codex standard. Disisi lain harga susu lokal lebih tinggi dari susu impor, membuat peternak lokal kalah bersaing dengan negara-negara pengekspor susu dunia. IPS di Indonesia lebih memilih menggunakan susu impor dengan kualitas lebih baik dan harga lebih murah dari susu lokal (Nugroho et al., 2011). Oleh karena itu perlu dicari upaya pemanfaatan susu untuk mengurangi kerugian peternak atau bahkan dapat meningkatkan pendapatan dengan usaha pengolahan susu tersebut. Salah satu alternatif yang dapat dilakukan dan dikembangkan adalah dengan pembuatan permen karamel susu (Abubakar dan Ilyas, 2005)

Penganekaragaman produk olahan susu sangat penting mengingat masyarakat sangat menggemari berbagai produk diversifikasi yang inovatif dan menyehatkan. Pada saat sekarang dimungkinkan untuk memberi flavor yang diinginkan pada permen karamel, baik flavor alami maupun sintetis. Karamel merupakan produk individual sehingga lebih sulit untuk dilakukan standarisasi produk (Koswara, 2009). Permen karamel susu yang dikenal selama ini pada umumnya berbahan dasar susu saja sebagai pembentuk cita rasa.Oleh karena itu perlu penelitian lebih lanjut terhadap pembuatan permen karamel dengan berbagai cita rasa (flavor) yang disukai (Abubakar dan Ilyas, 2005). Penganekaragaman produk permen karamel susu perlu dikembangkan lebih lanjut, misalnya dengan penambahan ekstrak jahe (Rismunandar, 1988; Purwanti, 1999) dan tanaman herbal lain yang memiliki aroma khas seperti temulawak .

Pramitasari (2010) mengatakan bahan kandungan jahe seperti halnya jenis rempah-rempah yang lain juga memiliki kemampuan mempertahankan kualitas pangan yaitu sebagai antimikrobia dan antioksidan. Sementara itu, pati temulawak yang memiliki kandungan kurkuminoid dapat digunakan sebagai campuran pati bahan lain untuk mengurangi sifat basi. Pembuatan permen karamel susu yang ditambahkan tepung jahe dan temulawak yang memiliki berbagai senyawa kimia yang bermanfaat serta memiliki citarasa yang khas diharapkan dapat memperbaiki sifat fisik dan kimia serta sifat organoleptik produk permen karamel susu.

Penelitian ini bertujuan untuk menganalisis karakteristik produk meliputi fisik, kimia, dan organoleptik terhadap permen karamel susu setelah adanya penambahanjahe dan temulawak, serta meningkatkan daya terima produk diversifikasi pangan yang berasal dari olahan hasil ternak. 


\section{MATERI DAN METODE}

Penelitian ini dilaksanakan pada bulan April sampai bulan Mei tahun 2014 di Laboratorium Jurusan Peternakan Fakultas Pertanian Universitas Bengkulu. Bahan yang digunakan yaitu susu segar yang diperoleh dari peternakan sapi perah rakyat di Kecamatan Selupu Rejang, Kabupaten Rejang Lebong, Bengkulu. Bahan lainnya yaitu tepung atau bubuk jahe dan temulawak, gula pasir, tepung agar agar dan mentega. Alat yang digunakan untuk membuat permen karamel susu antara lain kuali anti lengket, baskom, pengaduk alumunium, kompor gas, loyang, ayakan 40 mash, plastik klip dan kantong plastik.

\section{Pembuatan Permen Karamel}

Penelitian ini diawali dengan studi pendahuluan pembuatan permen karamelsusu.Bahan yang digunakan sebagai acuan untuk menentukan komposisi pada perlakuan lain yaitu temulawak, karena temulawak memiliki rasa pahit sehingga untuk mendapatkan jumlah maksimal agar dapat ditambahkan kedalam bahan makanan. Jumlah temulawak yang digunakan pada penelitian pendahuluan yaitu $5 \%, 3 \%, 1 \%$ dan $0,6 \%$.

Pembuatan permen diawali dengan menyampurkan dan memanaskan susu, gula, tepung jahe atau temulawak sesuai dengan jumlah perlakuan dengan terus menerus diaduk sampai terbentuk cairan kental. Selanjutnya, tepung agar-agar dan mentega ditambah sambil terus diaduk. Pemanasan dihentikan setelah mencapai kekentalan yang diinginkan. Untuk mengetahui adonan sudah menjadi karamel, masukan sedikit adonan dalam wadah berisi air dingin, apabila adonan membentuk bulatan yang utuh, maka siap untuk dicetak. Adonan dibiarkan dingin dan mengeras didalam cetakan. Proses tersebut dilakukan berulang sesuai dengan jumlah ulangan yang digunakan pada penelitian.

Berdasarkan uji organoleptik panel terbatas, tingkat penggunaan temulawak kedalam permen karamel sebanyak 5\% dan $3 \%$ menghasilkan citarasa yang sedikit pahit, sedangkan perlakuan $1 \%$ dan $0,6 \%$ menghasilkan cita rasa khas temulawak dan manis. Selanjutnya, jumlah temulawak $1 \%$ dan $0,6 \%$ menjadi rekomendasi yang digunakan sebagai perlakuan pada penelitian utama dengan perlakuan lainnya yaitu penambahan jahe dengan komposisi yang sama.

\section{Rancangan Penelitian}

Rancangan yang digunakan adalah Rancang Acak Lengkap (RAL) dengan lima perlakuan dan masing-masing empat kali ulangan antara lain.P0 : Permen karamel susu tanpa perlakuan sebagai kontrol, P1 : Permen karamel susu dengan penambahan $0,6 \%$ bubuk jahe, P2 : Permen karamel susu dengan $1 \%$ bubuk jahe, P3 : Permen karamel susu dengan $0,6 \%$ bubuk temulawak dan P4 : Permen karamel susu dengan $1 \%$ bubuk temulawak.

Variabel yang diamatiyaitu sifat fisik meliputi rendemendan kerapatan, sifat kimia meliputi $\mathrm{pH}$, kadar air, protein, lemak, dan nilai kalori atau energi. Pengujian organoleptik meliputi warna, aroma, rasa, tekstur, tingkat kehalusan dan tingkat keempukan serta penilaian produk 
secara umum.Penentuan rendemen dilakukan dengan cara menghitung permen karamel yang dihasilkan dari setiap perlakuan yang dinyatakan dalam persen (Purwanti, 1999). Pengukuran nilai kerapatan ditentukan dengan cara mengukur massa (g) dibagi dengan volume permen $\left(\mathrm{cm}^{3}\right)$ (Handayani, 2007). Untuk $\mathrm{pH}$ permen diukur dengan alat $\mathrm{pH}$ meter sampai menunjukkan angka konstan.Prosedur dan penghitungan kadar air dilakukan dengan metode oven (Legowo dan Nurwantoro, 2004). Kadar lemak dianalisis menggunakan metode sokhlet. Analisis protein dilakukan dengan menggunakan metode Kjehldahl
(Legowo dan Nurwantoro, 2004). Pengukuran nilai energi menggunakan bomb kalorimeter PARR 1261 (Patabang, 2009).

Uji organoleptik terdiri atas uji hedonik dan uji intensitas atribut sensori meliputi warna, aroma, rasa, tekstur, dan penilaian umum. Selain penggunaan skala hedonik, tingkat kesukaan panelis juga ditentukan dengan menghitung nilai modus kesukaan yaitu diwakili angka 6 dan 7 untuk menentukan persentase produk yang paling disukai dari kelima perlakuan yang berbeda. Tabel 1. dibawah ini menerangkan skala hedonik yang digunakan pada penelitian ini.

Tabel 1. Parameter uji organoleptik berdasarkan skala hedonik

\begin{tabular}{lll}
\hline \multicolumn{1}{c}{ Warna,aroma, rasa, tekstur* } & Parameter uji organoleptik & \multicolumn{1}{c}{ Keempukan $* *$} \\
\hline $1=$ sangat tidak suka & 1 = sangat keras & $1=$ sangat kasar $/$ tekstur \\
$2=$ tidak suka & $2=$ keras & $2=$ kasar \\
$3=$ agak tidak suka & $3=$ agak keras & $3=$ agak kasar \\
$4=$ netral & $4=$ biasa & $4=$ biasa \\
$5=$ agak suka & $5=$ agak renyah & $5=$ agak lembut $/$ halus \\
$6=$ suka & $6=$ renyah & $6=$ lembut $/$ halus \\
7 = sangat suka & $7=$ sangat renyah & $7=$ sangat lembut \\
\hline
\end{tabular}

Keterangan: *Sumber : Soekarto, 1985; Handayani, 2007 **Sumber : Abubakar dan Ilyas (2005)

\section{Analisis data}

Data yang diperolehkhususnya data fisik dan kimia dianalisis dengan ANOVA (Analysis of Variance). Jika perlakuan berpengaruh nyata dilakukan uji lanjut Duncan Multiple Range Test (DMRT). Data hasil pengujian organoleptik berdasarkan modus penerimaan dianalisis secara deskriptif.

\section{HASIL DAN PEMBAHASAN}

\section{Sifat fisik}

Hasil pengukuran sifat fisik dapat dilihat pada Tabel 2. Rendemen merupakan hasil yang diperoleh melalui perbandingan antara bobot bahan keluaran dengan bobot bahan awal (Rahingtyas, 2008). Tidak terdapat perbedaan yang nyata terhadap persentase rendemen. Rendemen yang dihasilkan tertinggi $41,62 \%$ dan terendah 40,14\%. Hal ini menunjukkan bahwa penambahan tepung jahe dan tepung temulawak sebanyak $0,6 \%$ dan $1 \%$ tidak memberikan pengaruh yang nyata terhadap jumlah rendemen permen karamel jika dibandingkan dengan perlakuan kontrol. 
Tabel 2. Rataan nilai sifat fisik ( rendemen dan nilai kerapatan ) permen karamel.

\begin{tabular}{lccccc}
\hline \multirow{2}{*}{ Parameter } & \multicolumn{5}{c}{ Perlakuan } \\
\cline { 2 - 6 } & $\mathrm{P} 0$ & $\mathrm{P} 1$ & $\mathrm{P} 2$ & $\mathrm{P} 3$ & $\mathrm{P} 4$ \\
\hline Rendemen $(\%)$ & $40,89 \pm 3,12$ & $40,65 \pm 0,99$ & $40,88 \pm 0,84$ & $40,14 \pm 1,98$ & $41,62 \pm 1,16$ \\
Kerapatan $\left(\mathrm{g} / \mathrm{cm}^{\mathbf{3}}\right)$ & $1,075 \pm 0,13$ & $1,146 \pm 0,17$ & $1,083 \pm 0,09$ & $1,098 \pm 0,13$ & $1,022 \pm 0,12$ \\
\hline Keterangan : P0 :Perlakuan kontrol, P1 : 0.6\% jahe, P2 : 1\% jahe, P3 : 0.6\% temulawak, P4: 1\% temulawak
\end{tabular}

Nilai kerapatan menunjukkan perbedaan yang tidak nyata $(\mathrm{P}>0,05)$.Nilai kerapatan tertinggi terdapat pada perlakuan P4 dengan penambahan temulawak sebanyak $1 \%$ yaitu $0,989 \mathrm{~g} / \mathrm{cm}^{3}$ dan terendah pada $\mathrm{P} 1$ dengan penambahan jahe $0,6 \%$ sebesar $0,887 \mathrm{~g} / \mathrm{cm}^{3}$. Hasil penelitian ini memberikan indikasi bahwa penambahan jahe dan temulawak meningkatkan kerapatan permen karamel.

\section{Sifat kimia}

Hasil pengujian sifat kimia permen karamel disajikan pada Tabel 3 berikut ini.

Tabel 3. Nilai rataan hasil analisis kimia permen karamel.

\begin{tabular}{|c|c|c|c|c|c|}
\hline \multirow{2}{*}{ Parameter } & \multicolumn{5}{|c|}{ Perlakuan } \\
\hline & $\mathrm{P} 0$ & $\mathrm{P} 1$ & $\mathrm{P} 2$ & P3 & $\mathrm{P} 4$ \\
\hline $\mathrm{pH}$ & $5,23 \pm 0,75$ & $5,08 \pm 0,50$ & $5,48 \pm 0,40$ & $5,53 \pm 0,05$ & $5,48 \pm 0,28$ \\
\hline Kadarair $(\%)^{*}$ & $10,34 \pm 2,62$ & $9,28 \pm 1,58$ & $9,34 \pm 0,91$ & $8,50 \pm 1,56$ & $10,68 \pm 0,82$ \\
\hline Lemak $(\%)^{*}$ & $5,25 \pm 1,64$ & $6,21 \pm 1,41$ & $6,27 \pm 1,40$ & $6,57 \pm 0,41$ & $5,67 \pm 2,27$ \\
\hline Protein $(\%) *$ & $5,18 \pm 0,37$ & $5,72 \pm 0,60$ & $5,47 \pm 0,22$ & $5,50 \pm 0,19$ & $5,57 \pm 0,07$ \\
\hline Energi (kkal)* & 4140,25 & 4140,75 & 4116,50 & 4096,50 & 3994,50 \\
\hline
\end{tabular}

Keterangan : Keterangan : P0=Perlakuankontrol, P1=0.6\%jahe, $\mathrm{P} 2=1 \%$ jahe, $\mathrm{P} 3=0.6 \%$ temulawak, $\mathrm{P} 4=1 \%$ temulawak *Hasilanalisis Laboratorium INTP IPB.

Nilai rata-rata $\mathrm{pH}$ permen karamel berada pada kisaran 5,08 (P1) sampai 5,53 (P3). Kelima perlakuan tidak menunjukkan perbedaan yang nyata $(\mathrm{P}>0.05)$ terhadap rataan nilai $\mathrm{pH}$ permen. Angka tersebut lebih rendah dari penelitian yang telah dilakukan oleh Purwanti (1999) dengan $\mathrm{pH}$ berkisar antara 6,69-6,99. Nilai tersebut masih berada pada kisaran normal. Handayani (2007) menyatakan nilai $\mathrm{pH}$ dapat berubah-ubah akibat adanya aktifitas mikroorganisme. Hal ini dikarenakan berbagai jenis mikroorganisme dapat berkembang pada berbagai tingkat keasaman, antara lain khamir $(\mathrm{pH} 2,5-8,5)$ dan kapang (pH 5-7).
Kadar air merupakan indikator penting yang harus diketahui, karena menentukan tingkat ketahanan terhadap daya simpan dari produk itu sendiri. Hasil penelitian menunjukkan rataan kadar air terendah terdapat pada perlakuan P3 atau permen karamel dengan $0,6 \%$ tepung temulawak yaitu $8,50 \%$ dan kadar air tertinggi yaitu $10,68 \%$ dari perlakuan P4 atau permen karamel dengan $1 \%$ tepung temulawak. Berdasarkan analisis ragam rataan kadar air menunjukkan hasil yang tidak berbeda nyata $(\mathrm{P}>0.05)$. Berdasarkan klasifikasi oleh Buckle et al. (1985) maka permen karamel hasil penelitian ini dapat diklasifikasikan 
kedalam karamel lunak dengan kadar air $10 \%$ dan sedang dengan kadar air $8 \%$.

Umumnya kandungan lemak susu sapi segar yaitu 3,25\% (Legowo, 2002) namun hasil analisis proksimat terhadap kandungan lemak pada permen karamel yang berbahan dasar susu kadar lemaknya mengalami peningkatan berkisar antara $5,25 \%$ dan $6,57 \%$. Tidak terdapat perbedaan yang nyata $(\mathrm{P}>0.05)$ terhadap kandungan lemak permen karamel. Hal ini diduga karena susu yang digunakan sebagai bahan utama pembuatan karamel berasal dari ternak sapi yang sama. Tingginya kadar lemak juga dipengaruhi oleh adanya tambahan mentega pada setiap perlakuan yang mengandung sebagian besar lemak, yaitu sekitar $81 \%$ dari total mentega yang digunakan.

Nilai biologis makanan dapat ditingkatkan dengan membuat campuran yang tepat. Sejumlah kecil protein hewani dapat meningkatkan mutu protein nabati dalam jumlah yang besar, dengan demikian penganekaragam menu sangat penting sebab dengan cara ini mutu protein bahan makanan saling mendukung dan meningkat (Winarno, 1993).

Nilai rataan tertinggi kadar protein sebesar 5,72\% terdapat pada P1 dengan perlakuan $0,6 \%$ tepung jahe, sedangkan rataan terendah terdapat pada $\mathrm{P} 0$ atau tanpa perlakuan sebesar 5,18\%, Pemberian tepung jahe dan temulawak sebanyak $0,6 \%$ dan $1 \%$ tidak menunjukkan perbedaan yang nyata $(\mathrm{P}>0.05)$ terhadap peningkatan kadar protein permen karamel yang dihasilkan.

Energi GE merupakan gambaran dari nilai kalori hasil pembakaran karbohidrat, lemak dan protein. Sumber energi yang utama dari berbagai jenis makanan berasal dari karbohidrat. Menurut Winarno (1997), karbohidrat banyak terdapat dalam bahan nabati, baik berupa gula sederhana, heksosa, pentosa, maupun karbohidrat dengan berat molekul yang tinggi seperti pati, pektin, selulosa dan lignin. Koswara (2009) menyatakan komposisi terbanyak dari semua jenis permen adalah sukrosa (gula pasir) dan gula lainnya (glukosa, sukrosa atau gula alkohol). Hal ini diperlukan untuk menghasilkan kemanisan dan keawetan atau daya simpannya. Selain dari gula, sumbangan energi juga diduga berasal dari mentega yang merupakan sumber lemak dengan nilai kalori yang besar. Sehingga dari segi gizi dapat dikatakan bahwa hampir semua jenis permen merupakan sumber energi (kalori).

Nilai GE tertinggi terdapat pada P2 yaitu 4140,75 kkal dan terendah pada P4 sebesar 3994,50 kkal. Analisis ragam terhadap kandungan gross energy menunjukkan hasil yang tidak berbeda nyata. Secara umum dari semua perlakuan, nilai rata-rata GE lebih besar dari nilai kalori sukrosa yaitu 3,95 kal/gram.

\section{Penilaian Organoleptik}

\section{Skor terhadapTekstur dan Keempukan}

Data yang diperoleh dari penilaian terhadap kehalusan atau tekstur dikelompokkan berdasarkan modus penerimaan dan nilai rataan berdasarkan skala hedonik. Dikatakan oleh Winarno (1997) tekstur dan konsistensi suatu bahan akan mempengaruhi citarasa yang ditimbulkan oleh bahan tersebut. 
Berdasarkan modus penerimaan, produk yang paling digemari panelis yaitu $\mathrm{P} 0$ atau permen karamel yang tidak menggunakan perlakuan jahe dan temulawak, yaitu sebesar 47,50\%. Penilaian panelis terhadap tekstur karamel dari lima perlakuan ratarata berkisar antara 4,48 - 4,04 yang berarti penilaian panelis antara biasa dan sedikit halus atau lembut. Analisis ragam menunjukkan bahwa dari kelima perlakuan menunjukkan tidak ada perbedaan yang nyata $(\mathrm{P}>0.05)$ dari skor yang diberikan panelis terhadap tingkat kehalusan tekstur permen karamel.
Berdasarkan analisis ragam, perlakuan penambahan jahe dan temulawak tidak berpengaruh nyata terhadap tingkat keempukan karamel yang dihasilkan. Rata-rata skor yang diberikan panelis berkisar antara 5,25 dan 4,54 (agak renyah). Menurut Abubakar dan Ilyas (2005) tingkat keempukan susu karamel berkaitan erat dengan kadar air dan karakteristik produk olahan susu. Rataan skor penilaian panelis terhadap tingkat kehalusan dan keempukan karamel disajikan pada Tabel 4.

Tabel 4. Rataan skor penilaian panelis terhadap tingkat kehalusan dan keempukan karamel

\begin{tabular}{lccccc}
\hline \multirow{2}{*}{ Parameter } & \multicolumn{5}{c}{ Perlakuan } \\
\cline { 2 - 6 } & P0 & P1 & P2 & P3 \\
\hline Tekstur & $4,48 \pm 0,32$ & $4,21 \pm 0,29$ & $4,26 \pm 0,33$ & $4,04 \pm 0,17$ & $4,15 \pm 0,26$ \\
Keempukan & $5,25 \pm 0,28$ & $4,83 \pm 0,26$ & $4,80 \pm 0,33$ & $4,54 \pm 0,07$ & $4,60 \pm 0,43$ \\
\hline Keterangan : P0 :Perlakuan kontrol, P1: $0.6 \%$ jahe, P2 : $1 \%$ jahe, P3 : $0.6 \%$ temulawak, P4 : $1 \%$ temulawak.
\end{tabular}

Modus Penerimaan terhadap Warna, Aroma, Rasa dan Penerimaan Umum

Modus penerimaan oleh panelis dikelompokan berdasarkan jumlah skor terbanyak dari skala hedonik yang telah ditentukan yaitu angka 6 (suka) dan angka 7 (sangat suka). Hasil analisis data pada Tabel 5 menunjukkan bahwa terjadi penurunan persentase modus penerimaan dengan adanya perlakuan. Hal tersebut diduga adanya penambahan bahan lain pada produk sangat mempengaruhi penerimaan oleh panelis karena hasil akhir dari pengolahan tersebut memiliki ciri yang tidak lepas dari bahan perlakuan yang ditambahkan, seperti warna, aroma, rasa dan penerimaan umum.

Tabel 5. Nilai rataan hasil uji organoleptik permen karamel.

\begin{tabular}{lcccc}
\hline \multirow{2}{*}{ Parameter } & \multicolumn{4}{c}{ Perlakuan } \\
\cline { 2 - 5 } & P0 & P1 & P2 & P3 \\
\hline Warna & 52,50 & 38,75 & 36,25 & 18,75 \\
Aroma & 37,50 & 31,25 & 36,25 & 16,25 \\
Rasa & 56,25 & 46,25 & 32,50 & 11,25 \\
Penerimaan umum & 58,75 & 42,50 & 32,50 & 13,75 \\
\hline
\end{tabular}

Keterangan : $\mathrm{P} 0=$ Perlakuan kontrol, $\mathrm{P} 1=0.6 \%$ jahe, $\mathrm{P} 2=1 \%$ jahe, $\mathrm{P} 3=0.6 \%$ temulawak, $\mathrm{P} 4=1 \%$ temulawak.

Produk berwarna dapat terbentuk dengan memanaskan bahan pangan. Pemanasan zat warna yang murni mengakibatkan karakteristik warna dari zat warna menjadi berubah (Desrosier, 1988).
Berdasarkan penilaian penerimaan panelis terhadap karamel yang ditambahkan tepung jahe dan tepung temulawak, tingkat kesukaan panelis terhadap warna karamel dengan modus tertinggi yang artinya 
paling banyak disukai oleh panelis terdapat pada P1 atau kontrol sebanyak 52,50\% dan paling rendah adalah perlakuan P3 atau perlakuan $0,6 \%$ temulawak dengan angka $18,75 \%$.

Secara kimiawi sulit dijelaskan mengapa senyawa-senyawa menyebabkan aroma yang berbeda. Aroma makanan banyak menentukan kelezatan bahan makanan tersebut. Pada umumnya aroma yang diterima oleh hidung dan otak lebih banyak merupakan berbagai ramuan atau campuran empat macam aroma utama yaitu harum, asam, tengik dan hangus. (Winarno, 1997). Modus kesukaan antara angka 6 dan 7 yang menunjukkan kesukaan terhadap aroma karamel tertinggi pada perlakuan P0 sebesar 37,50\% dan modus terendah pada perlakuan $\mathrm{P} 4$ sebesar $13,75 \%$.

Citarasa suatu bahan pangan adalah suatu respon ganda dari bau dan rasa. Bila digabungkan dengan perasaan (konsistensi dan tekstur) dari makanan didalam mulut, konsumen dapat membedakan satu makanan dengan jenis makanan yang lain.
Pemanasan dapat mengakibatkan degradasi kedua penyusun citarasa dan sifat-sifat fisik bahan pangan (Desrosier, 1988). Berdasarkan penerimaan panelis terhadap rasa permen karamel, produk yang paling disukai panelis yaitu P0 sebesar 56,25\% dan cenderung mengalami penurunan sampai pada perlakuan P4 dengan angka terendah sebesar 11,25\%. Terjadinya penurunan tingkat kesukaan terhadap rasa permen karamel diduga berhubungan dengan aroma dan rasa dari jahe dan temulawak yang ditambahkan pada perlakuan. Penambahan jahe akan menimbulkan sedikit rasa pedas sedangkan temulawak akan menimbulkan sedikit rasa pahit. Secara umum panelis lebih menyukai permen karamel dengan aroma susu dari pada karamel yang ditambahkan bahan lainya.

Penerimaan umum merupakan penilaian panelis terhadap penampilan hasil kombinasi seluruh atribut produk (Paramita, 2008). Hasil modus penerimaan umum produk oleh panelis disajikan pada Gambar 1.

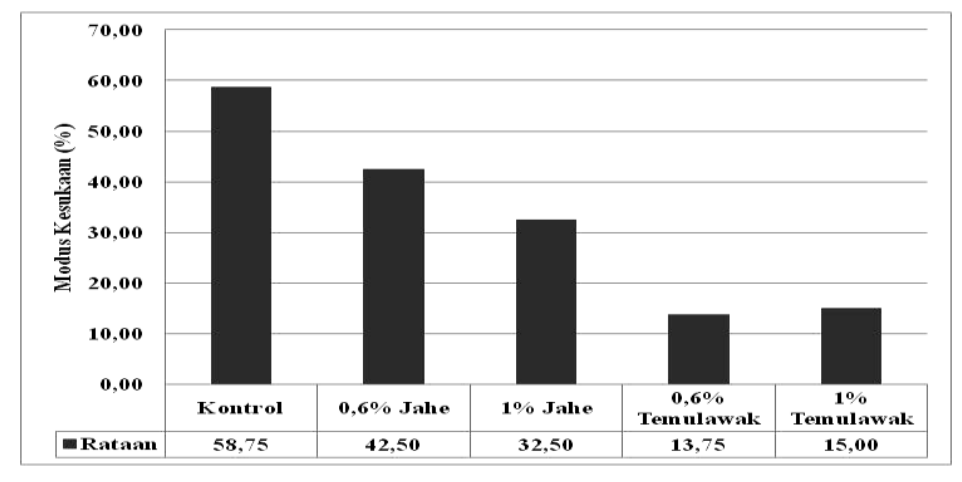

Gambar 1. Rataan modus penerimaan panelis terhadap produk secara umum.

Gambar 1 menunjukkan rataan hasil penerimaan umum panelis terhadap produk. Penerimaan umum panelis terhadap produk merupakan interpretasi dari karakteristik yang sudah diamati terlebih dahulu yaitu warna, aroma, rasa 
dan kehalusan atau tekstur. Berdasarkan persentase angka yang didapatkan, panelis telah mampu mengidentifikasi variabel bahan tambahan yang berkaitan dengan permen karamel yang dihasilkan. Selain beberapa parameter organoleptik dalam pengujian skala hedonik, penilaian produk suatu makanan secara keseluruhan sangat penting karena kesukaan konsumen terhadap suatu produk tidak hanya dipengaruhi oleh satu faktor. Berdasarkan hasil penelitian, modus dengan skor yang menunjukkan nilai kesukaan yaitu 6 dan 7 , persentase terbesar diperoleh P0 dengan angka 58,75\%, sedangkan tingkat kesukaan paling rendah $13,75 \%$ adalah P3 $=$ karamel dengan temulawak $0,6 \%$.

\section{SIMPULAN DAN SARAN}

\section{Simpulan}

Berdasarkan angka yang diperoleh, pembuatan karamel dapat memperbaiki sifat kimia produk karamel sebagai produk olahan yang berasal dari susu dengan meningkatnya nilai nutrisi permen karamel diantaranya kadar lemak berkisar 5,25 6,57 , protein 5,18 - 5,72, dan energi 3994,50 - 4140,75 kkal.

Penambahan jahe dan temulawak menurunkan tingkat kesukaan panelis terhadap aroma $(37,5 \%$ - 13,75\%), warna $(52,50 \%-18,75 \%)$, rasa $(56,25 \%$ $11,25 \%)$, tekstur $(47,50 \%-7,50 \%)$, skor kehalusan $(4,48-4,04)$, skor keempukan $(5,25$ - 4,54) serta penerimaan produk secara umum $(58,75 \%$ - 13,75\%). Pengolahan susu menjadi karamel dapat meningkatkan mutu produk karamel susu namun penggunaan jahe dan temulawak menurunkan persentase tingkat kesukaan panelis dibandingkan dengan karamel tanpa penambahan jahe dan temulawak.

\section{Saran}

Diperlukan penelitian lanjutan untuk mengetahui daya simpan dan kandungan antioksidan dari produk karamel yang ditambahkan jahe dan temulawak, sehingga akan diketahui ketahanan produk dari aktifitas mikroorganisme, dan dapat diketahui khasiatnya terhadap kesehatan karena mengandung berbagai senyawa antioksidan dari jahe dan temulawak yang ditambahkan.

\section{DAFTAR PUSTAKA}

Abubakar dan M. Ilyas. 2005. Mutu susu karamel asal susu pecah selama penyimpanan. Seminar Nasional Teknologi Peternakan dan Veteriner 2005.

Afriani, Suryono dan H. Lukman., 2011. Karakteristik dadih susu sapi hasil fermentasi beberapa starter bakteri asam laktat yang diisolasi dari dadih asal Kabupaten Kerinci. Agrinak. Vol . 01 No. 1: 36-42 ISSN: 2088-8643.

Buckle, K.A, R.A Edwards, G.H. Fleet, dan M. Wooton. 1985. Ilmu Pangan. Terjemahan oleh $\mathrm{H}$. Purnomo dan Adiono. Jakarta. Penerbit Universitas Indonesia.

Desrosier, N.W. 1988. Teknologi pengawetan pangan edisi ketiga, diterjemahkan oleh Muchji Muljohardjo. Jakarta. Penerbit Universitas Indonesia (UI-Press). 
Handayani, E. 2007. Pembuatan karamel dari susu sapi (kemasan) dan karakterisasi fisik serta pHnya. Skripsi. Departemen Fisika. Fakultas Matematika dan Ilmu Pengetahuan Alam. Institut Pertanian Bogor.

Koswara, S. 2009. Teknologi pembuatan permen. Ebookpangan.com.

Legowo, A. M. dan Nurwantoro. 2004. Diktat Kuliah Analisis Pangan. Program Studi Teknologi Hasil Ternak. Fakultas Peternakan. Universitas Diponegoro. Semarang.

Legowo, A.M. 2002. Diktat Kuliah: Sifat kimiawi, fisik dan mikrobiologis susu. Program Studi Teknologi Hasil Ternak Fakultas Peternakan Universitas Diponegoro. Semarang.

Nugroho W. P. S., D. Pudjotomo, and T. K. Tifani. 2011. Analisa penyebab penurunan daya saing produk susu sapi dalam negeri terhadap Susu Sapi Impor pada Industri Pengolahan Susu (IPS) dengan Metode Fault Tree Analysis (FTA) dan Barrier Analysis. Program Studi Teknik Industri Universitas Diponegoro Semarang. J@TI Undip, Vol VI No 2.

Paramita, D. 2008. Kualitas Mikrobiologis Set Yoghurt Sinbiotik dengan Pemanbahan Natamicin Sebagai Biopreservatif. Skripsi. Program Studi Teknologi Hasil Ternak.
Fakultas Peternakan. Institut Pertanian Bogor.

Patabang, D. 2009. Analisis nilai kalor secara eksperimental dan teoritik dari briket arang kulit kemiri. Majalah ilmiah "Mektek" Tahun XI No.3 September 2009.

Pramitasari, D. 2010. Penambahan ekstrak jahe (Zingiber officinale Rosc) dalam pembuatan susu kedelai bubuk instan dengan metode spray drying: komposisi kimia, sifat sensoris dan aktivitas antioksidan. Skripsi. Program Studi Teknologi Hasil Pertanian. Fakultas Pertanian. Universitas Sebelas Maret. Surakarta.

Purwanti, Y. 1999. Sifat Fisik, Kimia Dan Organoleptik Permen Karamel Susu Jahe. Skripsi. Jurusan Ilmu Produksi Ternak. Fakultas Peternakan. Institut Pertanian Bogor.

Rahingtyas, D.K. 2008. Pemanfaatan Jahe (Zingiber officinale) sebagai Tablet Isap untuk Ibu Hamil dengan Gejala Mual dan Muntah. Skripsi. Program Studi Gizi Masyarakat dan Sumberdaya Keluarga. FEMA. Institut Pertanian Bogor.

Winarno, F. G. 1997. Kimia Pangan dan Gizi. PT Garmedia Pustaka Utama. Jakarta.

Winarno, F.G. 1993. Pangan Gizi, Teknologi dan Konsumen. PT Gramedia Pustaka Utama. Jakarta. 